\title{
Vitality of aquatic plants and microbial activity of sediment in an oligotrophic lake (Lake Bohinj, Slovenia)
}

\author{
Mateja GERM* and Tatjana SIMČIČ́ ${ }^{1)}$ \\ University of Ljubljana, Biotechnical faculty, Jamnikarjeva 101, SI-1000 Ljubljana, Slovenia \\ ${ }^{1)}$ National Institute of Biology, Večna pot 111, SI-1000 Ljubljana, Slovenia \\ *e-mail corresponding author: mateja.germ@bf.uni-lj.si
}

\begin{abstract}
The vitality of eight macrophyte species and the microbial activity of sediment in an oligotrophic lake (Lake Bohinj, Slovenia) were studied via the terminal electron transport system (ETS) activity of mitochondria. The levels of ETS activity of vascular plants were as follows: Ranunculus circinatus, Myriohpyllum spicatum, Potamogeton alpinus, P. perfoliatus, P. lucens. Fontinalis antipyretica exhibited the highest ETS activity of the non-vascular plants, followed by charales Chara delicatula and C. aspera. High values enable R. circinatus, an amphibious species with rapid growth, to survive under conditions in which the water level changes throughout the season. M. spicatum, a species with broad ecological tolerance, also exhibited high ETS activity. The ETS activity of the microbial community in sediment was affected by temperature and/or the amount and origin of the organic matter. A positive correlation between the ETS activity of the sediment and that of $\mathrm{M}$. spicatum and $\mathrm{R}$. circinatus was measured, while negative correlations or no correlation were observed for mosses and macroalgae. The high ETS activity in sediment indicates rapid mineralization of organic matter and, in turn, sufficient nutrients for growth of macrophytes.
\end{abstract}

Key words: macrophytes, mineralization, respiratory activity

\section{INTRODUCTION}

Macrophytes play an important role in the balancing of lake ecosystems (Hutchinson 1975). They are able to improve water quality by absorbing nutrients with their effective root system. At the same time, their death and decay increases nutrient concentration. In oligotrophic ecosystems, the primary productivity of phytoplankton and macrophytes is limited by nutrient concentration due to rapid recycling of nutrients that are assimilated immediately after mineralization (López-Archilla et al. 2004).

Environmental factors, such as water-column nutrient, light, temperature and sediment type, have a profound effect on both the growth and reproduction of macrophytes (Barrett et al. 1993; Janauer 2001; Jiang et al. 2008). Temperature affects dormancy, development of turions, levels of photosynthesis and respiration, and the time of emergence of macrophytes, in addition to many other factors (Pip 1989).

Interaction between macrophytes and sediment can be measured by microelectrode measurements with the oxygen microsensor system (Laskov et al. 2006). However we decided to measure respiratory activity of both components that is less time consuming and gives good results (Simčič \& Germ 2010). When organisms are exposed to stress and demand more energy, ATP production and $\mathrm{O}_{2}$ consumption are increased in the mitochondria (Packard 1985; Bartoli et al. 2005). The respiratory potential can be measured via the terminal electron transport system (ETS) activity in mitochondria. The enzyme assay for the respiratory electrontransport-system is an indirect method for estimating potential electron transport associated with respiration (Packard 1971). The ratio between respiratory potential measured via ETS activity and aerobic dark respiration rate in intact organs in macrophytes was between 0.08 and 0.35 (Mazej \& Gaberščik 1999) and 0.18-0.38 (Peňuelas 1988). It means that most species usually use only a small part of respiratory enzymes.

Most aquatic phanerogams possess a system of interconnected internal gas lacunas (Armstrong 1972). By this system, oxygen is transported to the underground parts of the plants (Sand Jensen et al. 2005). Part of the oxygen transported downwards is released in the root zone, where it sustains a number of beneficial oxidation processes (Laanbroek 2010). Releasing oxygen from roots to the surrounding rhizosphere is a process that is known as radial oxygen loss (ROL) (Inoue \& Tsuchiya 2008). Substantial ROL is important for the survival and fitness of aquatic plants. Radial oxygen loss is demonstrated to affect a number of microbial and chemical reactions occurring within sediments, in particular in oligotrophic systems (Karjalainen et al. 2001). Furthermore, the rhizosphere has plant-derived organic carbon compounds, such as exudates and decaying root materials, and heterotrophic bacteria utilize these organic carbon compounds as electron donors to generate energy (Bodelier 2003). Oxygen-releasing plants thus should substantially influence elemental cycles in aquatic ecosystems (Pinardi et al. 2009; Laanbroek 2010). 
Exchange of nutrients between sediment and the overlying water always takes place, so that sediment conditions will inevitably influence the sediment-water interface and the overlying water conditions such as nutrients and physical-chemical, light and other conditions, finally affecting plant growth (Yu et al. 2010). Cebrian et al. (1998) claimed that the turnover and fate of organic matter and associated nutrients in ecosystems depends on the type of dominant primary producer. Thus, ecosystems dominated by plants with a rapid turnover of biomass support higher rates of herbivory and accumulate less carbon than systems dominated by those with a slower turnover of biomass (Cebrain \& Duarte 1994). It has been shown that, in nutrient-poor waters, the nutrient uptake from sediment becomes the main nutrient source for rooted aquatic vascular plants (Carignan \& Kalff 1980; Rattray et al. 1991). Sediments are typically 1000 -fold richer in both nutrients (especially $\mathrm{N}$ ) and carbon than the water column, thereby providing a highly concentrated growth medium for heterotrophic bacteria (Pace \& Prairie 2005).

Primary production in oligotrophic lakes is limited by low amounts of nutrients, which may be below the limit of detection, particularly in summer (Elser et al. 1990). Since ETS measurements include both aerobic and anaerobic microbial activities (Packard 1971; Broberg 1985), the total microbial respiratory potential in the sediments is measured. For that reason, the ETS activity has been frequently applied as an estimator of microbial activity in freshwater sediments (G.-Tóth et al. 1994; Simčič \& Brancelj 2002; Muri \& Simčič 2004). We have therefore measured the activity of ETS in sediment as an indicator of intensity of mineralization that, in turn, constitutes a direct supply of nutrients for macrophytes.

The aim of this study was to find out the difference in behaviour of submerged vascular aquatic vegetation and non-vascular aquatic vegetation, in their interaction with the sediment. We expect that vascular plants will have strong interaction with sediment on the contrary to mosses and algae. We also expect that the physiological activity of macrophytes with high energy demands will be related to the intensity of mineralization processes in sediment.

\section{MATERIAL AND METHODS}

\subsection{Study location}

Lake Bohinj is the deepest and largest natural lake in Slovenia. It has several permanent and temporary surface and sub-surface tributaries, and one outflow is the River Sava Bohinjka. The surface of the lake covers 3.18 $\mathrm{km}^{2}$ and the maximum depth is $45 \mathrm{~m}$. The hydraulic retention time is $0.3 \mathrm{y}$. The catchment area of the lake is more than $100 \mathrm{~km}^{2}$. Lake Bohinj is a dimictic oligotrophic lake with relatively low concentrations of total phosphorus (annual mean $7 \mu \mathrm{g} \mathrm{P} \mathrm{L}^{-1}$ ), total nitrogen
(0.85 $\left.\mathrm{mg} \mathrm{N} \mathrm{L}^{-1}\right)$ and chlorophyll- $a\left(1.6 \mu \mathrm{g} \mathrm{L}^{-1}\right)$. The average Secchi depth is around $9 \mathrm{~m}$.

Epilimnion and littoral water temperatures ranged from $5{ }^{\circ} \mathrm{C}$ in February to $21.2{ }^{\circ} \mathrm{C}$ in August in 2007. Oxygen saturation in the littoral was $100 \%$ or more during the vegetation period, but decreased to nearly $70 \%$ during winter and autumn. Conductivity was around $200 \mu \mathrm{S} \mathrm{cm}^{-1}$ during late autumn and winter and decreased in spring and summer in the littoral and epilimnion (180 $\mu \mathrm{S} \mathrm{cm}^{-1}$ ). The maximal concentrations were: nitrate 2.65 mg N-NO ${ }_{3}^{-} \mathrm{L}^{-1}$, sulphate $1.99 \mathrm{mg} \mathrm{SO}{ }_{4}^{2-} \mathrm{L}^{-1}$ and ammonium $0.048 \mathrm{mg} \mathrm{N}-\mathrm{NH}_{4}{ }^{+} \mathrm{L}^{-1}$. Phosphate and nitrite concentrations were below the limits of detection throughout the year (i.e., below $0.035 \mathrm{mg} \mathrm{PO}_{4}{ }^{3-} \mathrm{L}^{-1}$ and $0.01 \mathrm{mg}$ $\left.\mathrm{N}-\mathrm{NO}_{2}^{-} \mathrm{L}^{-1}\right)$. The highest concentration of total phosphorus $\left(31 \mu \mathrm{g} \mathrm{P} \mathrm{L}^{-1}\right)$ was observed in the littoral in June. The concentration of total nitrogen varied between 0.77 and $1.15 \mathrm{mg} \mathrm{N} \mathrm{L}^{-1}$.

\subsection{Sampling}

Samples were collected monthly from the littoral in 2007, except in January and March. Water samples were taken using van Dorn water bottles (Wildco), and sediment samples using a van Veen grab (Eijkelkamp). In order to get a representative sediment sample, the uppermost, $5 \mathrm{~cm}$ deep, sediment layers were taken for analysis from three samples of an approximately $10 \mathrm{~cm}$ deep sediment layer which was taken by the grab. Water samples were collected for chlorophyll- $a$ and chemical analysis at one depth $(3 \mathrm{~m})$ in the littoral zone. Samples were transported to the laboratory and analyzed within 24 hours.

The presence and abundance of macrophytes in littoral were assessed from a boat, using a rake with hooks. The following species were included in measurements: Myriophyllum spicatum, Potamogeton perfoliatus, $P$. alpinus, P. lucens, Ranunculus circinatus, Fontinalis antipyretica, Chara delicatula and C. aspera. The presence and abundance of macrophytes were estimated at two representative localities in the lake that were chosen after surveying the whole lake from the boat.

Water transparency was measured as the Secchi depth. Temperature, conductivity, and oxygen saturation were measured using a multi-probe (MultiLineP4, WTW).

\subsection{Chemical and biochemical analyses}

Chlorophyll- $a$ (Chl- $a$ ) was determined in triplicate in water filtered through Whatman $\mathrm{GF} / \mathrm{C}$ micro glass fibre filters. Chl- $a$ was measured following the methods described by Jeffrey \& Humphrey (1975). The concentrations of nitrite, nitrate, phosphate, sulphate and ammonium were determined using ion exchange chromatography (Metrohm, 761 Compact IC). Total phosphorus and total nitrogen were analysed by the standard methods (APHA et al. 1998). 
Terminal electron transport system (ETS) activity was measured using the assay originally proposed by Packard (1971), and modified by many authors (Kenner \& Ahmed 1975; G.-Tóth 1999). Samples of macrophytes $(0.006-0.02 \mathrm{~g})$, were homogenized in $4 \mathrm{~mL}$ final volume of ice-cold homogenization buffer $(\mathrm{pH}=8.4)$ using a glass Potter (Eurostar; Ika Labortechnik) for 3 min at $500 \mathrm{rpm}$, followed by ultrasonic homogenization (4710; Cole-Parmer, Vernon Hills, IL, USA) for $20 \mathrm{sec}$ at $40 \mathrm{~W}$. The sediment samples were homogenized in 4 $\mathrm{mL}$ final volume using an ultrasonic homogenizer for 3 $\min$. The homogenates were centrifuged for $4 \mathrm{~min}$ at 0 ${ }^{\circ} \mathrm{C}$ at $10,000 \mathrm{rpm}$ (2K15, Sigma). Within $10 \mathrm{~min}, 0.5$ $\mathrm{mL}$ of supernatant (in triplicate) was incubated in 1.5 $\mathrm{mL}$ substrate solution and $0.5 \mathrm{~mL}$ 2-(p-iodophenyl)-3(p-nitrophenyl)-5-phenyl tetrazolium chloride (INT) reagent solution for $40 \mathrm{~min}$ at standard $\left(20^{\circ} \mathrm{C}\right)$ temperature. Formazan production was determined spectrophotometrically from the absorbance of the sample at $490 \mathrm{~nm}$ against the blank within $10 \mathrm{~min}$ of stopping the reaction (WTW photoLabSpektral). ETS activity was calculated according to Kenner \& Ahmed (1975).

The surface layer $(0-5 \mathrm{~cm})$ of the sediment profile was mixed well with a glass rod, because degradation of organic matter increased with depth in the upper sediment profile (Muri \& Simčič 2004). Samples of sediment were placed on pre-weighed aluminium foil and weighed on an electrobalance (Sartorius) to the nearest $0.1 \mathrm{mg}$. The amount of organic matter in sediments was determined by loss-on-ignition according to procedure which minimizes carbonate loss (Dean 1974). Sediment was oven-dried in a ceramic vessel $\left(24 \mathrm{~h}, 105^{\circ} \mathrm{C}\right)$. Dried sediment was weighed, then burned at $520{ }^{\circ} \mathrm{C}$ for $3 \mathrm{~h}$ and weighed again.

\subsection{Statistical analysis}

One-way analysis of variance (ANOVA) was used to test the differences of ETS activity in sediment between sampling dates, and two-way ANOVA to analyze the differences of ETS activity between macrophyte species and between sampling dates as fixed factors. Tukey HSD post hoc test was used to determine which means differed significantly. To minimize inhomogeneous variability, all data were log transformed. Correlations between macrophyte ETS activity and temperature and between macrophyte and sediment ETS activities were estimated using Pearson's correlation coefficient (r). All statistical analyses were conducted in SPSS 13.0.

\section{RESULTS}

\subsection{Respiratory activity of macrophytes}

$R$. circinatus and $M$. spicatum exhibited the highest ETS activities in vascular plants, followed by $P$. alpinus, $P$. perfoliatus, and $P$. lucens. F. antipyretica exhibited the highest ETS activity in non-vascular plants, followed by charales C. delicatula and C. aspera (Fig. 1).
Low ETS activity was observed in the leaves of $M$. spicatum early in the spring, in April. The ETS activity of young shoots appearing in May was twice as high (Fig. 1). The lowest ETS activity was measured in December in the case of $R$. circinatus. The opposite, high ETS activity in the end of the year was observed in the leaves of $P$. perfoliatus, $P$. lucens and $F$. antipyretica (Fig. 1).

\subsection{Respiratory activity of sediments}

ETS activity in sediments varied from $8.5 \mu \mathrm{L} \mathrm{O}$ $\mathrm{g}^{-1} \mathrm{DM} \mathrm{h}^{-1}$ in April to $67.3 \mu \mathrm{L} \mathrm{O}_{2} \mathrm{~g}^{-1} \mathrm{DM} \mathrm{h}^{-1}$ in July (Fig. 2) and differed significantly between sampling dates (ANOVA, $F=332 ; p<0.001$ ). A positive correlation was observed between the ETS activity of the microbial community in sediment and temperature $(r=0.41, p<0.05)$.

The amount of organic matter in sediment increased throughout the year, reaching its maximal value at the end of the growing season (Fig. 2).

\subsection{Relationship between macrophytes and sediments}

The correlation between the ETS activities of the sediment and the two macrophyte species M. spicatum and $R$. circinatus was significantly positive (Tab. 1). Both species also reached the highest ETS activities among vascular plants. Negative correlations between the ETS activities of the sediment and $P$. perfoliatus, $P$. lucens, $F$. antipyretica and $C$. delicatula were observed. No correlation was observed between the ETS activities of the sediment and that of $P$. alpinus and $C$. aspera (Tab. 1).

\section{DISCUSSION}

\subsection{Respiratory activity of macrophytes}

ETS activities in vascular plants were in the following order: $R$. circinatus, $M$. spicatum, $P$. alpinus, $P$. perfoliatus, $P$. lucens. $F$. antipyretica exhibited the highest ETS activity of the non-vascular plants, followed by the two chara species $C$. delicatula and $C$. aspera (Fig. 1). R. circinatus, which is an amphibious species thriving in shallow waters as well as on land, exhibited the highest ETS activity potential. The high values enable this species to survive under conditions in which the water level changes throughout the season. Organisms react economically in response to environmental change. Rapid adaptation is important for plants thriving in an environment in which temperature changes quickly. The metabolism of plants in ideal conditions is adapted in such a way that respiration is maintained at a constant level, despite alteration of temperature (Hagihara \& Hozumi 1991). Generations are short lived in the case of $R$. circinatus and new plants appear very often and grow very fast (Dalhgren \& Cronberg 1996), which demands high ETS activity. $M$. spicatum was another species that exhibited high ETS activity (Fig. 1). 

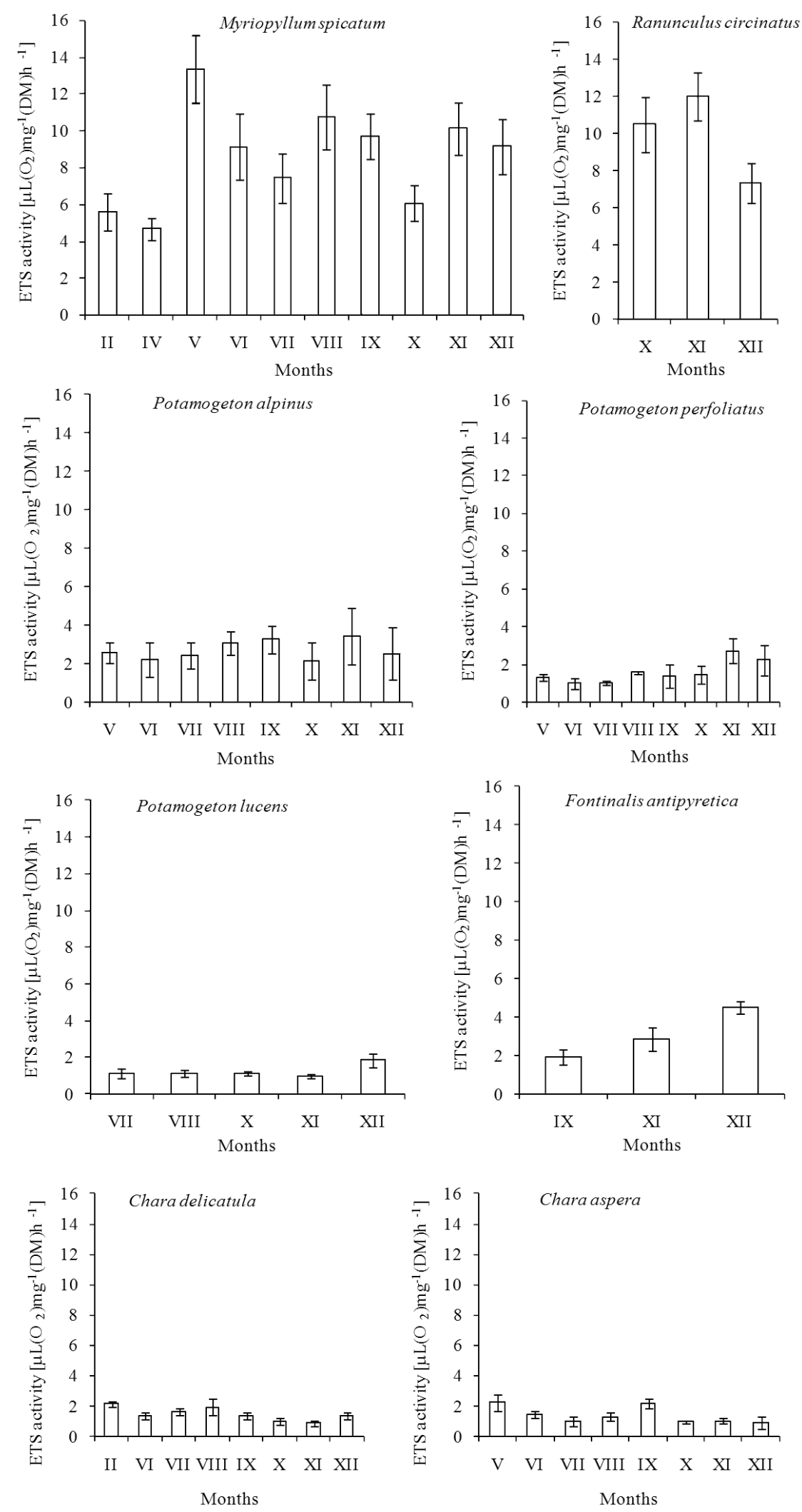

Fig. 1. ETS activity of macrophytes Ranunculus circinatus, Myriohpyllum spicatum, Potamogeton alpinus, P. perfoliatus, P. lucens, Fontinalis antipyretica, Chara delicatula and C. aspera (mean $\pm \mathrm{SD}, \mathrm{n}=12)$. 


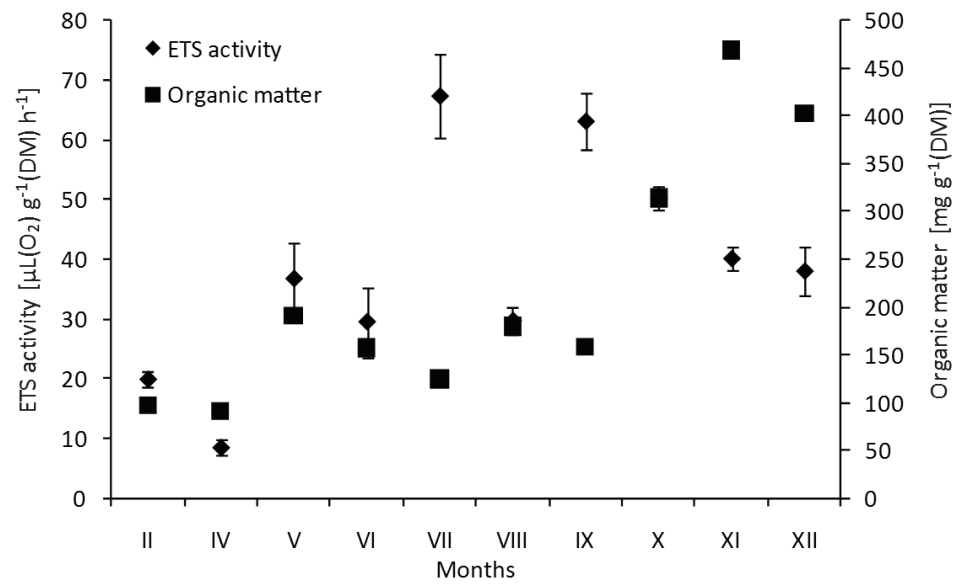

Fig. 2. ETS activity and organic matter content of sediments (mean $\pm \mathrm{SD}, \mathrm{n}=12$ ).

Tab. 1. Correlation coefficients $(r)$ between electron transport system (ETS) activity of eight macrophyte species and that of sediment. NS: not significant $(p$ $>0.05$ ).

\begin{tabular}{lc}
\hline Species & Pearson's correlation coefficient \\
\hline Myriohpyllum spicatum & 0.230 \\
Potamogeton perfoliatus & -0.211 \\
P. alpinus & $0.026^{\mathrm{NS}}$ \\
P. lucens & -0.274 \\
Fontinalis antipyretica & -0.733 \\
Ranunculus circinatus & 0.346 \\
Chara delicatula & -0.278 \\
Chara aspera & $0.007^{\mathrm{NS}}$ \\
\hline
\end{tabular}

It throve in the lake throughout the year. Plants that emerge earlier can take up limited nutrients or shade the species that emerge later. Early emergence thus results in competitive advantage (Van den Berg et al. 1998). M. spicatum grows rapidly to the water surface by utilizing stored carbohydrates (Herb \& Stefan 2006). It was also found to achieve a higher ETS activity than other aquatic plants in the study of Penuelas et al. (1988). It is concluded that this is related to the wide ecological amplitude, in terms of resource tolerance, allowing this species to grow well in infertile sediments (Wang et al. 2008), as is the case in Lake Bohinj. The leaves of $M$. spicatum that overwintered showed low ETS activity early in the spring while young shoots, that appeared in May, exhibited as much as twice that ETS activity (Fig. 1). Similar results were also reported for the aquatic plants M. spicatum and P. crispus (Mazej \& Gaberščik 1999). Plants require additional energy during intensive growth and development in order to build structural components. The higher ratio of metabolically active to inactive tissue resulted in higher respiratory potential in developing shoots. It was evidenced that respiratory rates of pea leaves decrease continuously during leaf maturation, which may result from the decreasing ability of the leaf cells to fully utilize their potential enzymatic capacity or may be a direct consequence of decrease in the respiratory enzymatic capacity of the leaf (Smillie 1962). Spe- cies of the genus Potamogeton exhibited significantly lower ETS activity. Fontinalis antipyretica and Chara spp. grew in deeper water layers under relatively stable environment conditions, which was reflected in low ETS activity (Fig. 1). Under optimal environmental conditions bryophytes have lower metabolic rates and grow more slowly than angiosperms (Smith 1983).

\subsection{Respiratory activity of sediments}

ETS activity in sediments varied significantly with time, the highest values being observed in July and September (Fig. 2). Relexans (1996b) proposed that ETS activity measured at constant temperature can be considered as an estimator of microbial biomass, which contributes, in most cases, the greatest part of the sediment respiratory potential. The increase of respiratory potential in sediments in summer time was therefore probably caused by the higher microbial production rate. The positive correlation between ETS activity of sediment and temperature $(r=0.41, p<0.05)$ is in accord with the results of the laboratory study that showed that a relatively small increase in temperature induced significantly higher respiratory potential in sediments (Simčič \& Germ 2010). Törnblom \& Pettersson (1998) also evidenced that temperature was the main factor controlling seasonal changes in bacterial and total sediment metabolism. A relatively low ETS activity of sediment was observed in Lake Bohinj in August, in spite of the highest temperatures. It seems that the poor oxygen conditions for aerobic bacteria reflected in lower microbial activity. Törnblom \& Pettersson (1998) reported that, in late summer, decreasing bacterial production and total sediment metabolism coincided with decreasing sediment redox potential, implying that the availability of suitable electron acceptors for microbial respiration also played an important role in the control of bacterial and overall activity. Although ETS activity is measured in vitro after mixing and homogenization of sediment samples, and therefore at altered conditions, this method has a good accuracy to 
estimate the magnitude of respiratory metabolism in freshwater sediments (Broberg 1985). Moreover a significant correlation between ETS activity and oxygen consumption rate observed in freshwater sediments (Simčič \& Brancelj 2002; Muri \& Simčič 2004) supports the use of ETS activity as an indicator of the intensity of mineralization processes in this study.

The amount of organic matter in sediment increased throughout the year, reaching a maximal value at the end of the growing season (Fig. 2). Besides the predominating autochthonous organic material, the terrestrial allochthonous matter also contributed to whole organic material in Lake Bohinj (Vreča et al. 2008). Autochthonous organic matter is labile, and normally effectively degraded in the water column and surface sediments (Vosjan \& Olanczuk-Neyman 1977; Relexans 1996a). In contrast, terrestrial organic more refractory and a longer matter is period is needed to degrade these components to forms that can be further decomposed by bacteria (Muri \& Simčič 2004). ETS activities in sediments were therefore affected by temperature and by the amount and origin of the organic matter. The high ETS activities of the microbial community in sediments, however, indicate intensive mineralization processes. In summer time, detritus undergoes faster and more complete degradation and turnover, and regeneration of nutrients is therefore increased. Rapid and more fluctuating flow of organic matter and associated nutrients, and less accumulation of nutrients in slowly decomposable matter, cause more open and fluctuating nutrient cycles.

\subsection{Relationship between macrophytes and sediments}

A positive correlation was shown between the ETS activity of the sediment and that of the two species, $M$. spicatum and $R$. circinatus (Tab. 1). Negative correlations between the ETS activities of the sediment were observed for $F$. antipyretica, $C$. delicatula, and no correlation for C. aspera, among others (Tab. 1). This was expected, since non-vascular plants do not have permanent biochemical interactions with sediments (Wetzel 1975).

A positive correlation between the ETS activity of the sediment and M. spicatum and R. circinatus was expected, since they had the highest ETS activity of all eight species studied (Fig. 1). Fast growing species that produce high biomass, such as $M$. spicatum and $R$. circinatus, have high respiratory activity (Mazej \& Gaberščik 1999). The high productivity and biomass turnover of macrophytes in fertile ecosystems have been shown to contribute to high rates of nutrient mobilization from the sediment, particularly with rapidly growing species such as M. spicatum (Smith \& Adams 1986). Accumulated biomass in the lake sediment resulted in increased respiration there, as reported by Muri \& Simčič (2004). M. spicatum and R. circinatus grow very rapidly. As both have long and dense roots, they can have significant impact on the processes in the sediment. Releasing oxygen from roots of macrophytes to the surrounding rhizosphere affects the metabolic processes of microorganisms (Inoue \& Tsuchiya 2008). It is known that roots of studied species M. spicatum release oxygen that has profound affect on mineralization processes in the sediment (Laskov et al. 2006). Kleeberg et al. (2010) reported that macrophytes drive the evolution of a sedimentary $\mathrm{P}$ cycle by mobilizing and translocating $\mathrm{P}$, by accumulating carbon, and thus by stimulating microbial and redox processes. The wellaerated sediment in Lake Bohinj enables rapid mineralization of organic matter and, in turn, sufficient nutrients for growth of macrophytes. Nutrient dynamics with higher $\mathrm{N}$ and $\mathrm{P}$ were associated with higher litterassociated microbial biomass in the case of Lake Erie (Su et al. 2007). High ETS activity does not always mean higher turn-over of plants and/or increased biomass. Energy, provided by respiratory activity, is used for many processes and components, such as, production of reproductive organs and synthesis of secondary metabolites and protective substances (Gaberščik et al. 2002). The growth of macrophytes in Lake Bohinj will control further lake succession by intensifying the internal nutrient cycling.

\section{CONCLUSIONS}

The high respiratory potential reached by species $R$. circinatus enables it to survive under strongly changing environmental conditions, and by M. spicatum, accounts for its wide ecological tolerance. M. spicatum and $R$. circinatus had a clearer relationship with sediment microbial activity than moss $F$. antipyretica, and algae C. delicatula and C. aspera which do not have any permanent biochemical interaction with the sediment. Rapid and complete decomposition of the organic matter in sediment in Lake Bohinj resulted in rapid turnover and regeneration of nutrients.

\section{ACKNOWLEDGEMENTS}

We thank prof. Roger Pain for English revision of the manuscript and referees for the constructive comments. This research was financed by the Ministry of Higher Education, Science and Technology of the Republic Slovenia through the programs "Biology of plants" (P1-0212), and "Communities, relations and communications in the ecosystems" (P1-0255).

\section{REFERENCES}

APHA, AWWA \& WEF. 1998. Standard methods for the examination of water and wastewater. 20th ed., L.S. Clesceri, A.E. Greenberg \& A.D. Eaton (Eds), American Public Health Association, Washington DC: $1325 \mathrm{pp}$.

Armstrong, W. 1972. A re-examination of the functional significance of aerenchyma. Physiol. Plant., 27: 172-177.

Bartoli, C.G., F. Gomez, G. Gergoff, J.J. Guiamet \& S. Puntarulo. 2005. Up-regulation of the mitochondrial alternative oxidase pathway enhances photosynthetic electron 
transport under drought conditions. J. Exp. Bot., 56: 12691276.

Barrett, S.C.H., Eckert, C.G. \& B.C. Husband. 1993. Evolutionary processes in aquatic plant populations. Aquat. Bot., 44: 105-145.

Bodelier, P.L.E. 2003. Interactions between oxygen-releasing roots and microbial processes in flooded soils and sediments. In: H. de Kroon \& E.J.W. Visser (Eds), Root ecology. Series: Ecological Studies, vol 168. Springer, Berlin: 331-362.

Broberg, A. 1985. A modified method for studies of electron transport system activity in freshwater sediments. Hydrobiologia, 120: 181-187.

Dahlgren, G. \& N. Cronberg. 1996. Species differentiation and relationship in Ranunculus subgenus Batrachium (Ranunculaceae) elucidated by isozyme electrophoresis. Symb. Bot. Ups., 31: 91-104.

Dean, W.E.Jr. 1974. Determination of carbonate and organic matter in calcareous sediments and sedimentary rocks by loss on ignition: Comparison with other methods. $J$. Sediment. Petrol., 44: 242-248.

Elser, J.J., E.R. Marzolf \& C.R. Goldman. 1990. Phosphorus and nitrogen limitation of phytoplankton growth in the freshwaters of North America: a review and critique of experimental enrichments. Can. J. Fish. Aquat. Sci., 47: 1468-1477.

Carignan, R. \& J. Kalff. 1980. Phosphorus sources for aquatic weeds-water or sediments. Science, 207: 987-989.

Cebrian, J., M. Williams, J. McClelland \& I. Valiela. 1998. The dependence of heterotrophic consumption and $\mathrm{C}$ accumulation on autotrophic nutrient content in ecosystems. Ecol. Lett., 1: 165-170.

Cebrian, J. \& C.M. Duarte. 1994. The dependence of herbivory on growth-rate in natural plant-communities. Funct. Ecol., 8: 518-525.

Gaberščik, A., M. Germ, A. Škof, D. Drmaž \& T. Trošt Sedej. 2002. UV-B radiation screen and respiratory potential in two aquatic primary producers: Scenedesmus quadricauda and Ceratophyllum demersum. Verh. Int. Ver. Theor. Angew. Limnol., 27: 422-425.

G.-Tóth, L. 1999. Aktivität des Elektronentransportsystems. In: W. von Tümpling \& G. Friedrich (Eds), Biologische Gewässeruntersuchung. Methoden der Biologischen Wasseruntersuchung 2, Gustav Fischer Verlag, Jena, Stuttgart, Lübeck, Ulm: 465-473.

G.-Tóth, L., Zs. Langó., J. Padisák \& E. Varga 1994. Terminal electron transport system (ETS)-activity in the sediment of Lake Balaton, Hungary. Hydrobiologia, 281: 129-139.

Herb, W.R. \& H.G. Stefan. 2006. Seasonal growth of submersed macrophytes in lakes: The effects of biomass density and light competition. Ecol. Model., 193: 560-574.

Hagihara, A. \& K. Hozumi. 1991. Respiration. In: A.S.J. Raghavendra (Ed.), Physiology of trees. Wiley, New York: 87-110.

Huthinson, G.E. 1975. A Treatise on Limnology. Vol. 3, Limnological botany. J. Wiley \& Sons, New York: 660 pp.

Jeffrey, S.W. \& G.F. Humphrey. 1975. New spectrophotometric equations for determining chlorophylls a, b, c1 and c2 in higher plants, algae and natural phytoplankton. Biochem. Phyriol. Pflanzen, 167(8s): 191-194.

Inoue, T.M. \& T. Tsuchiya. 2008. Interspecific differences in radial oxygen loss from the roots of three Typha species. Limnology, 9: 207-211.

Kenner, R.A. \& S.I. Ahmed. 1975. Measurements of electron transport activities in marine phytoplankton. Mar. Biol., 33: 119-127.

Kleeberg, A., C. Herzog, S. Jordan \& M. Hupfer. 2010. What drives the evolution of the sedimentary phosphorus cycle? Limnologica, 40(2): 102-113.
Janauer, G.A. 2001. Is what has been measured of any direct relevance to the success of the macrophyte in its particular environment? J. Limnol., 60(Suppl. 1): 33-38.

Jiang, J.H., C.F. Zhou, S.Q. An, H.B. Yang, B.H. Guan \& Y. Cai. 2008. Sediment type, population density and their combined effect greatly charge the short-time growth of two common submerged macrophytes. Ecol. Eng., 34: 79-90.

Karjalainen, H., G. Stefansdottir, L. Tuominen \& T. Kairesalo. 2001. Do submersed plants enhance microbial activity in sediment? Aquat. Bot., 69: 1-13.

Laanbroek, H.J. 2010. Methane emission from natural wetlands: interplay between emergent macrophytes and soil microbial processes. A mini-review. Ann. Bot., 105: 141-153.

Laskov, C., O. Horn \& M. Hupfer. 2006. Environmental factors regulating the radial oxygen loss from roots of Myriophyllum spicatum and Potamogeton crispus. Aquat. Bot., 84: 333-340.

López-Archilla, A.I., S. Molla, M.C. Coleto, M.C. Guerrero \& C. Montes. 2004. Ecosystem metabolism in a Mediterranean shallow lake (Laguna de Santa Olalla, Doñana National Park, SW Spain). Wetlands, 24: 848-858.

Mazej, Z. \& A. Gaberščik. 1999. ETS-activity as a measure of vitality of different macrophyte species. Phyton, 39: 181-185.

Muri, G. \& T. Simčič. 2004. Respiratory activity in sediments in three mountain lakes of the Julian Alps and in subalpine Lake Bled (Slovenia): an effect of altitude and antropic influence. Aquat. Microb. Ecol., 34: 291-299.

Pace, M.L. \& Y.T. Prairie. 2005. Respiration in lake. In: P.J. Leb. Williams \& P. del Giorgio (Eds), Respiration in Aquatic Ecosystems. Oxford University Press: 103-121.

Packard, T.T. 1971. The measurement of respiratory electrontransport activity in marine phytoplankton. J. Mar. Res., 29: 235-244.

Packard, T.T. 1985. Measurement of electron transport activity of microplankton. In: H. Jannash \& P.J.Leb. Williams (Eds), Advances in aquatic microbiology. Academic Press, London. 3: 207-261.

Peňuelas, J., J. Murillo \& J. Azcón-Bieto. 1988. Actual and potential dark respiration rates and different electron transport pathways in freshwater aquatic plants. Aquat. Bot., 30: 353-362.

Pip, E. 1989. Water temperature and freshwater macrophyte distribution. Aquat. Bot., 34: 367-373.

Pinardi, M., M. Bartoli, D. Longhi, U. Marzocchi, A. Laini, C. Ribaudo \& P. Viaroli. 2009. Benthic metabolism and denitrification in a river reach: A comparison between vegetated and bare sediments. J. Limnol., 68(1): 33-145.

Rattray, M.R., C. Howard-Williams \& J.M.A. Brown. 1991. Sediment and water as sources of nitrogen and phosphorus for submerged rooted aquatic macrophytes. Aquat. Bot., 40: $225-237$.

Relexans, J.C. 1996a. Measurement of the respiratory electron transport system (ETS) activity in marine sediments: stateof-the-art and interpretation. I. Methodology and review of literature data. Mar. Ecol. Prog. Ser., 136: 277-287.

Relexans, J.C. 1996b. Measurement of the respiratory electron transport system (ETS) activity in marine sediments: stateof-the-art and interpretation. II. Significance of ETS activity data. Mar. Ecol. Prog. Ser., 136: 289-301.

Sand-Jensen, K., O. Pedersen, T. Binzer \& J. Borum. 2005. Contrasting oxygen dynamics in the freshwater isoetid Lobelia dortmanna and the marine seagrass Zostera marina. Ann. Bot., 96: 613-623.

Simčič, T. \& A. Brancelj. 2002. Intensity of mineralization processes in mountain lakes in NW Slovenia. Aquat. Ecol., 36: 345-354

Simčič, T. \& M. Germ. 2010. Increased temperature due to global warming alters the respiratory potential in aquatic 
organisms from an oligotrophic lake. Internat. Rev. Hydrobiol., 95: 370-382.

Smillie, R.M. 1962. Photosynthetic \& respiratory activities of growing pea leaves. Plant Physiol., 37: 716-721.

Smith, A.J. 1983. Bryophyte Ecology. Chapman and Hall, London: $511 \mathrm{pp}$.

Smith, C.S. \& M.S. Adams. 1986. Phosphorus transfer from sediments by Myriophyllum spicatum. Limnol. Oceanogr., 31: 1312-1321.

Su, R., R.N. Lohner, K.A. Kuehn, R. Sinsabaugh \& R.K. Neely. 2007. Microbial dynamics associated with decomposing Typha angustifolia litter in two contrasting Lake Erie coastal wetlands. Aquat. Microb. Ecol., 46: 295-307.

Törnblom, E. \& K. Pettersson. 1998. Bacterial production and total sediment metabolism in profundal Lake Erken sediments. Advanc. Limnol., 51: 177-183.

Vreča, P., C. Stalicas, G. Muri, V. Daskalou, T. Kanduč \& A. Leis. 2008. C and N elemental and stable isotopic signa-

Received: March 2010

Accepted: May 2011 tures in sedimentary organic matter from Lake Pamvotis (Greece) and Lake Bohinj (Slovenia). Geologija, 51: 65-70.

Van den Berg, M.S., H. Coops, J. Simons \& A. de Keizer. 1998. Competition between Chara aspera and Potamogeton pectinatus as a function of temperature and light. Aquat. Bot., 60: 241-250.

Vosjan, J.H. \& K.M. Olanczuk-Neyman. 1977. Vertical distribution of mineralization processes in a tidal sediment. Neth. J. Sea Res., 11: 14-23.

Wang, J.W., D. Yu \& Q. Wang. 2008. Growth, biomass allocation, and auto fragmentation responses to root and shoot competition in Myriophyllum spicatum as a function of sediment nutrient supply. Aquat. Bot., 89: 357-364.

Wetzel, G.R. 1975. Limnology. W.B. Saunders Company, Philadelphia (US): 734 pp.

Yu, H.C., C. Ye, X.F. Song \& J. Liu. 2010. Comparative analysis of growth and physio-biochemical responses of Hydrilla verticillata to different sediments in freshwater microcosms. Ecol. Eng., 36: 1285-1289. 